\title{
SOCIAL CONSTRUCTION ON CULTURAL MULTICULTURALISM
}

\author{
Sukamto $^{1}$, I Nyoman Ruja², Agus Purnomo ${ }^{3}$
}

Received April 18, 2018, Published May 9, 2018

(C) Author (2018)

\begin{abstract}
This paper aims to disseminate the results of the study and get feedback about the "Social construction on Multiculturalism". Five years ago Ahimsa Putra states that the face of Indonesia as pluralism without multiculturalism. Until now the problem of multiculturalism has become something that must be kept alive in an attempt to minimize the incidence of national disintegration. Winter tried to rethink multiculturalism by taking a lesson from Canada, that Canada has experienced setbacks in implementing the work program of multiculturalism. While Pakulski looks at the implementation of multiculturalism policy program in Australia as a blur. Scuzzarello, with optimism, invites to care about multiculturalism and share power on different communities. Gozdecka (et al), in recent years after the multicultural declared, stated that it is a failure both in Europe and in Anglophone West. This study was conducted in Blitar, using a qualitative approach to data collection methods and also interviews with ten informants. As a result, the construction of the community regarding multiculturalism: they consider themselves as the brother. In addition they also describe that: (a) assert one's cultural identity, study and assess the cultural heritage of a person; (b) respect and desire to understand and to learn about (and from) cultures besides their culture; (c) assessing and were delighted with the difference in the culture itself, which saw that the presence of groups from different cultures in the community as a positive thing to be respected and maintained. The harmony was found both in everyday lives, especially in the Religious and National holidays, for example, Eid Al-Fitr, Vesak, Christmas, and others religious holiday. Other examples, it also happens during the commemoration of National Holiday such as the Independence Day, the Youth Pledge Day, and the others.
\end{abstract}

Key word's: Identity, Multiculture, Social Construction

\section{INTRODUCTION}

Five points (aspects) from reality typically can be summarized in God, Nature, Logic, People and Always. The first is a manifestation of religion, second is a manifestation of science, reason, universalism, and eternalism. The five points, by Zerubavel (2015), are regarded as five pillars in social construction a la Bergerian and Lukmannian. Partially, the phenomenon can be traced in social life as follow.

The phenomenon of the current social life and citizenship is slightly in chaos. There are groups of the resident which come against each other. Teenagers in a group attack the other one. In fact, the effect of the phenomenon resulted in miserable effect. From life victims, physical The other phenomenon long days before or before the regional head election, there would be conflicts on ethnic, religion, race and parties. Even that, the effect of the presidential election in 2014 still can be felt till nowadays.

\footnotetext{
Departement of Social Studies, Faculty Social Science, State University of Malang sukamto.fis@um.ac.id

Departement of Social Studies, Faculty Social Science, State University of Malang

Departement of Social Studies, Faculty Social Science, State University of Malang
}

Jurnal Teori dan Praksis Pembelajaran IPS Volume 3, No.1, 2018, 59-68 ISSN 2503-5307 
Ied Mubarak in Tolikara, Papua has disturbed with turmoil which causes a man/woman died and several of victims injured because of apparatus shot; also tens of kiosks and a musholla surrounding burnt. So far, there is news from many sources which part of it seems need verification. Yet, the other, unfortunately, in the limitation of information, it has "fried" the news to do provocation further to drive the issue to become a conflict, violence between Christian and Moslem - it is not only in Tolikara, but also Papua, moreover its scope is widened to Indonesia, maybe it also be widened to be discussed within Moslem-Christian in the world!

Furthermore, the theorists call attention to the need of being always resurrecting multicultural spirit. From this, it is significantly how important the need to see and to resurrect the nature and the attitude of multiculturalism. One effort to cultivate and to resurrect it is by trying to have studied on Society Construction on Multiculturalism Culture. The study roadmap has been especially shown in study method.

Shortly, Pierre L, van de Berghe (1969) pointed that the characteristics of basic natures of the plural society (multicultural) are: 1 ) there is segmentation in the form of groups which often have different subcultural one another; 2) it has social structure divided into non complementary institutions; 3) less developing consensus between the members toward basic values; 4) relatively, there are often conflicts between groups; 5) relatively, social integration growth on coercion and interdependent in economy; also 6) there is political domination by a group of another group (Nasikum, 2005: 40-41). How is the reality of those characters in social life?

\section{METHOD}

The embryo of this writing had been initiated and dig in the many forms of studies respectively: Quarrel on the border of Blitar regency and Kediri regency (Sukamto, 2013), identification of multiculturalism potency in Garum district, Blitar regency (Sukamto, 2014), society social construction in Ngaringan village on Multiculturalism in Ngaringan, Gandusari Blitar regency (Sukamto, 2015) and society in the southern slope of Kelud Mountain (Study on Social Construction of Multicultural in Blitar Regency (Sukamto, Nyoman Ruja and Agus Purnomo (2016-2018)).

The chosen paradigm in this study is phenomenology with the qualitative approach and with the descriptive study. The data is obtained in several ways from observation, conventional interview, and depth interview until through documentation. Meanwhile, data analysis was conducted by manifesting four stages, they are data collection (1), data presentation (2), data reduction or interpretation (3) and verification or deduction (4). As an attempt to strengthen validity, it is conducted triangulation whether, from source, theory and context also lengthen the participation in and within informants.

Ghozdecka et all (2014) in his writing "From multiculturalism to post multiculturalism: Trends and paradoxes". In the current years after multicultural was declared, it failed to conduct in Europe or in West Anglophone. This diagnoses will be lined with the focus of cultural practice that is culturally the society is varied, for instance: divorce, respecting murderer; the growth of political activity for anti-immigration and adopting stricter law regulation on immigration regions and the citizenship. This article is aimed to describe legally the social and political response to the failure of multiculturalism under the post culturalism charter. In the long studies, it also identifies the general (major) form and the characteristics of multiculturalism discus its implication specifically on citizenship in Europe and its surrounding. Especially, it also analyzes the new form in current areas of immigrant rights or migration law and many disputations on citizenship policy in Europe that occurs in various social and seems enriched multiculturalism. This description also directed through the literature of neoliberal government. In another hand, this article also shows paradox from post-multiculturalism and its implication on a different culture.

Winter (2015) in "Rethinking Multiculturalism After its "Retreat: Lessons From Canada" said that since the beginning of the 21st century, several countries until 1990 the 
implementation of multiculturalism policy is declined. Winter also shows how multiculturalism is as an idea and also normative framework, how is the immigration integration in Canada, a country which initiates multiculturalism.

\section{RESULT AND DISCUSSION Social Construction}

In the hemisphere, multiculturalism goes through various tidal situations. Winter (2015) presented the rethinking on multiculturalism after declining and get a lesson from Canada. Meanwhile, Laegaard (2015) questioned the contextuality and multiculturalism, on how it is relevant to political theory. As he made his reference to Carens, Bikhu Parekh, James Tully who describe contextual theories.

In Indonesia, as stated by Ahimsya Putra (2011), said that Indonesia as a country with plural society yet it is not multicultural. Afterward, Putra also stated that this reality should always be maintained and resurrected in every opportunity that society realizes how important to growth and maintain multiculturalism.

Pakulski (2014) in "Confusions about Multiculturalism" explain about multiculturalism of Australia, as the integrative strategic policy which is aimed to manage cultural difference - as adopted by the Australian government in the 1970s. This is original; Australian multiculturalism contains classic, integrative, reciprocal, egalitarian and respectful social theory in the majority. Somehow, it's confusing with ethnic plurality and intermixture (melting pot) simulation approach, this confusion is clear in European and domestic critic lately. Pakulski explains the framework and multiculturalism principles of Australian, identify foundation theory, and it's clearly such popular confusions on meaning, focus, and objective.

Scuzzarello, Sarah. 2015. "Caring Multiculturalism: Power and Transformation in Diverse Societies". In her article, she explained or gave alternative approach on multiculturalism theory which she called as "Caring multiculturalism" or multiculturalism care. Her reason was that without good intention, reproduction rhetoric of multicultural theory constructed by a group as the main entity (substantive) that live in small house and accommodating the change of power relation. Multiculturalism care describes ethic care; it is a critic of the phenoms group on multiculturalism and social psychology in discursive, except advocate group contextualization which claims the difference and country practice on multiculturalism.

As in discursive psychological framework, multiculturalism care is referred to individual identity or group as a relation, in political and negotiation, and it is not totality bias and it simply changed. In the same manner as feminism on multiculturalism which tries to analyze the change of gender power in full asymmetric relation between groups through advocacy with full attention and responsive approach on the need and claim from minority group and individual in it. Scuzzarello was also framing main points on multiculturalism care through illustration from multicultural practice in three cities in Europe lands.

If this tendency cannot be controlled, it would cause not the only disintegration of further

social-cultural, but also political disintegration. As stated above, it is the undeniable reality that Indonesian state-nation consists of the huge amount of ethnical group, culture, and religion, as a summary, Indonesian state-nation is simply regarded as "multicultural" society. Indonesian reality is suitable with Parekh (1997:167) definition that "just as a society with several religions or languages is multi-religious or multilingual, a society containing several cultures is multicultural. Therefore, once more, as formulated by Parekh that multicultural society is the one that includes several cultural communities with their overlapping, but none the less distinct conceptions of the world, systems of meaning, values, forms of social organizations, histories, customs, and practices."

The definition of "multiculturalism" given by experts is diverse. As described previously and also below, "multiculturalism" basically is world's view that they can be translated in several cultural policies - that emphasize on the acceptance toward diversity reality, plurality, 
and multicultural reality in social life. Multiculturalism can also be understood as a worldview which acknowledges existing cultural existence, apart from the huge and the small; this view is then called as politics of recognition.

With a variety of description and tendency in concept growth and multiculturalism practice, Parekh (1997:183-185) differentiate five kinds of multiculturalism. Of course, the division of these five multiculturalism forms is not "waterproof" (watertight), on the contrary, it can overlap in current sides.

Kind of "isolationism multiculturalism" refers to a society where several cultural groups run autonomy life and involved in minimum interaction with each other. Examples of this group are like society in "millet" system in Turki Usmani or Amish society in the US. This group accepts the diversity but at the same time tries to maintain their culture separately from other society, generally.

"Accommodative multiculturalism" model is plural society who has a dominant culture which makes an adjustment and current accommodation for the cultural need of minority. Accommodative multiculturalism society formulates and implements regulations, law and sensitive stipulations in cultural, and give freedom to the minority for maintaining and developing their culture; on the contrary, the minority is not challenging dominant culture. This accommodative multiculturalism can be found in England, France, and several other Europe countries.

There is also "autonomic multiculturalism", it is a plural society where main cultural groups try to realize equality with the dominant culture and desired an autonomy life in a political framework which collectively can be accepted. The main concern of this last cultural group is to maintain their life which have the same right with the dominant group; they challenge dominant cultural group and try to create a society where a group can exist as equal partners. This kind of multiculturalism is supported, for instance, by Quebecois group in Canada, and immigrant Moslem groups in Europe which demanded to be able to implement syari'ah, educate their children in an Islamic school and so on.

The variant of "critical" or "interactive multiculturalism" is a plural society where cultural groups are not really concerned with autonomy cultural life; yet, they are more demanding collective cultural realization which reflecting and confirming their distinctive perspectives. The dominant cultural group, of course, tends to reject it. And moreover, they try hard to implement their dominant culture by sacrificing culture from minority groups. Therefore, minority groups challenge the dominant culture group, intellectually or politically on purpose to create a conducive climate for simultaneous creation of a new egalitarian collective culture genuinely. This kind of multiculturalism, for example, is hard fought by the Black in United States, England, and others.

The last is "cosmopolitan multiculturalism", who try to eliminate cultural borders for creating a society where each individual is not bound and committed to current culture and, on the contrary, independently involved in some intercultural experiments and also develop each cultural life. The supporter of this multiculturalism, mostly, is diaspora intellectual and liberal groups which have a tendency of postmodernist that looks at all cultures as resources can be chosen and taken freely.

\section{Multicultural Identity}

The identity takes place in a process of being in the continuum of social change. Lately, the issue of identity or identity politics has been phenomenal, in a varied and terrifying form, whose effects are also unimaginable. What are the local conflicts occurring in Ambon, Aceh, Kalimantan, Papua and elsewhere in Indonesia are the last ethnic, cultural and religious conflict Friday 29 July 2016 in TanjungbalaiNorth Sumatra? The 61-year-old state of the Republic of Indonesia seems to be in an on-going situation, with problems arising after 18 years of reform. One day before the anniversary of the birth of Pancasila on June 1, 2006, was held "Symposium 
with the theme" Restoration Pancasila reconcile the Politics of Identity and Modernity "in Campus FISIP UI Jakarta. This is one picture of how the problem of Identity rising to Identity politics becomes a crucial issue today.

Various studies of identity, some are focused on place identity sometimes known as locus identity sometimes also territory identity ; a study by Neville (1997) has done because residence is not merely to stay, but also the place of ancestors, historically, socially and culturally embedded in the personal and collective identity of the people. All of them are united in the place or location of this globe of nature. In literature studies or literature which discusses the "place identity" that defines the place as a component of identity with regard to sex, social class, ethnic background, occupation, religion and so on (Prochaschy, 1983 in Utz, 2001: 48). Similarly, Utz gives the argument that the identity of the place can be the identity of the group and individual level (Utz, 2001: 9). Even with reference to broad actors, collectiveness and social institutions and cultural products, associations with rituals and experiences, the "identity sociology" can fully describe the relationship between social life and cultural foundation ( Cerulo, 1997: 401-402). In this study place the identity of the place as one in addition to the identity of the other more broadly.

Identity studies in resistance belong to both classical and contemporary sociological studies. Because the identity within him has existed since something was either an object or a human being and a collection of objects or human beings. An examination of identity has been pioneered by Cooley and Mead (Cerulo, 1997), and Woodward (in Haralambos and Holborn, 2004: 820) first by Mead, both Goffman and Freud's three psychoanalysts, even the result of making identity studies grow dominantly in 1970 until now as a sociology discourse. Similarly, group identity studies (collective identity, for the study of collective identity, has been pioneered by some sociologists, although one distinct from Durkheim with "collective consciousness", Marx with "class consciousness", Weber with " Verstehen " and Tonnies with " gemeinschaft ". On the contrary identity, the study is a study of sociology and contemporary problems because however classical, identity studies, the concept of identity is seen as a new concept, more related to technological development on the one hand and network society on the other (Castell, 2004). Castell to uncover Identity with cross-cultural analysis on social, economic and political issues in the world.

Identity becomes the basis of inequality, social categories, and differences. However, the importance of inequality, category, and division of identity differ from place to place, from time to time and from individual to individual. Haralambos and Holborn (2004: 824) distinguish there are three levels of identity: passive identity, active identity and political identity. The firstlevel identity is potential, while the second in which an individual is aware that the identity becomes the basis for his actions, the third level of an individual is not only conscious but in every political action based on his identity.

Indonesian society as part of the world community entered into a network society that processed in such a way, thus forming a network of informational society. For several decades after Indonesia's independence, the Indonesian media grew parallel to the interests of the State, even the media used as a tool of legitimacy and maintaining the identity of the nation. But from the 1990s, the Indonesian media began to flourish the internet and of course internet cafes (cafe). The seeds of reform began to grow in unison with the spread of internet media as a form of resistance identity (Castells, 2004, Sparringa, 2005) for the Indonesian nation.

While Valentin (1998) describes a comparison naming analysis in Japan and the UK. According to Valentin naming the other is one way of identification that helps the formation of self-definition ( self ). There is no agreement among scientists about the definition of identity, but most have the similarity that identity is a product of social construction (Valentin, 1998; Fearon, 1999; Castell, 2004), identity is never singular but compound (Moya, 2001; Sparringa, 2005 ;), complex (Mansfield, Gill, and Golander, 2006), multilayered ( Brickell, 2006), identity is always changing according to social context (Sparringa, 2005), identity is always invention

Jurnal Teori dan Praksis Pembelajaran IPS Volume 3, No.1, 2018, 59- ISSN 2503-5307 
(Grijp, 2004); Sparringa, 2005) in addition to the agreement ( Grijp , 2004), so identity is no more a configuration built over time. The most important function of identity as well as being a differentiator as well as a provider, identity also serves to increase solidarity (Hollinger, 2006) and social integration, although there is also the danger as a trigger of conflict.

The identity is expanded because it is considered to contribute greatly to economic analysis, on the grounds. First, the identity can be shortly described behavior that seems pretty destructive; both identities under new influences from outside, human actions or a person can be meaningful to respond to others; the three identities declare a new path/view and preference can be changed; the four identities are fundamental to the formation of behavior, then the choice of identity is largely important for one to take economic advantage (Arkelof and Kranton 2000: 717).

Identity differences are caused by historical and cultural differences ( Erikson in Manfield, Gill and Golander, July 2006). Because it is multidimensional and changes through the journey of life, the formation of personal identity, social identity, and cultural identity, identity is described as a vague, complex and growing.

Identity is also something ascribed in addition to being achieved. Identity is always changing according to historical and cultural journey and its social context. This includes the historical journey of resistance in claiming its rights. Therefore identity is always invention, in addition, is also a convention. Important elements Identities are diverse forms of physical examples of skin color, hair, eye to social nature eg history, nationality, gender, religious ethnicity, language tradition, dialect, class, lifestyle, ideology, belief and so on.

Similarly, the study of collective identity, because the study of collective identity has been initiated by some sociologists, although one concept is different from the others: Durkheim with "collective consciousness", Marx with "class consciousness", Weber with " Verstehen " and Tonnies with " gemeinschaft ". Identity becomes the basis of inequality, social categories, and differences. However, the importance of inequality, category, and division of identity differ from place to place, from time to time and from individual to individual. Haralambos and Holborn(2004: 824) distinguish there are three levels of identity: passive identity, active identity and political identity. The first-level identity is potential, while the second in which an individual is aware that the identity becomes the basis for his actions, the third level of an individual is not only conscious but in every political action based on his identity.

In the economic analysis, the concept of identity is expanded in meaning because it is thought to contribute great, four reasons. First, identity can explain behavior that seems destructive; both identities under new influences from outside, human actions or a person can be meaningful to respond to others; the three identities declare a new path/view and preference can be changed; the four identities are fundamental to the formation of behavior, then the choice of identity is largely important for one to take economic advantage (Arkelof and Kranton, 2000: 717). While Hudi (2001) suggests that the research agenda on identity is directed at (1) the importance of developing the scope of research on social identity, not only in the laboratory but also in the external environment including distance; (2) a deeper knowledge of interrelations and processes of identity formation and its development; (3) deeper understanding of the processes of identity development, it is necessary to characterize individuals whose dispositions are adopted by group or collective identity and (4) individual differences alone can never be complete to explain the development of identity.

According to Horton (2001), the term multiculturalism still creates confusion for various parties. Multiculturalism according to Horton appeared initially as an increase of the term of pluralism that applies to the diversity in society without any further improvement efforts. The term multiculturalism now refers to two meanings:

1. The issue of appropriate measures to accommodate the different interests or even ethnic opposites in a plural society.

2. The ideal form of plural society to be achieved 
The study of multiculturalism in America is very different from the study of multiculturalism in European countries. American Nagara is created from immigrants who form a plural society, a European state of immigrant arrivals thus creating a plural society. Meanwhile, the investigation into multiculturalism in Indonesia is increasingly important as the authoritarian government shifts as a result of the impact of colonialism, towards an increasingly democratic and more concerned government of minorities. Multiculturalism is necessary for minorities to have more space to contribute more to the state, not just to the attractions of a tourist attraction only so that it wants to break away like Timor Leste (Tarling: 2008).

The study of identity has been done by some earlier thinkers who have fallen into the category of modern sociological thinking. Through the work of Cooley and George Herbert Mead (Baldwin, 1986; Cronk, 2005), the identity is studied so that it grows as a center of thought in sociology discourse lately. In a microscopic perspective such as social psychology, symbolic interaction, this study focuses primarily on individual perspectives, evolving in works in the 1970s, sociologists focusing their studies on formations that distinguish relation to interpersonal interaction with self.

But according to Cerulo (1997) in the last two decades, more research leads to three things: the first national social movement and directed his attention to the issues of the activity of the group ( group agencies ) and political activity. As a result, this identity study shifts to the collective side (Snow, 2001; Utz, 2001) with gender/sexuality, race / ethnicity, and class forms. Both also focus attention on and identification processes, which in turn also lead to group or collective levels agency that also shows how those differences are created, maintained and changed. The three new communications technologies are also changing on the construction of self and place identity. Various researchers have also evolved to explore the substance of I, me and generalized others and how they are all negotiated to the birth of cyberspace or digital identity identities.

The identity refers to (a) the social category, by definition through members with various rules having characteristics as expected behavior, (b) socially distinguishable, in which one has special pride. In the present thinking identity is the dignity, honor, and pride of someone implicitly related to the social category. Identity can also refer to two things: first at the same time as a social category and the source of one's dignity or self-respect.

That identity must be found because it is one of the basic human needs. Heckert (2002) says without identity there is no employer or slave, boss or worker, male or female, white or black, leader or follower, heterosexual or homosexual11. Without a human identity cannot communicate with each other. Identity determines the status and role of a person and includes the basic characteristics of a person, whether physical or socio-cultural. The traditional identity is encircled by the primordial boundary in the form of a new identity bond, the national identity, that national identity does not abolish or meld its primordial identity, but overcome it, transcend it.

Identity is wholly a social product and cannot exist or exist outside the cultural, social and acculturation representations. Identity is expressed through the forms of representation that we and others know. Identity is the essence of which can be signified ( signified ) to mark the sign, tastes, beliefs, attitudes, and lifestyles. Identity must be both personal and social, (Frable, 1997, Huddy, 2001); identities associated with similarities and differences with personal and social things and with forms of representation. Identity is best understood not as a fixed entity, but as a picture of a self-filled with emotional content. Our self-image reflects an essential identity.

Self-identification as a man or woman is the basis of an identity that is usually seen as a function of the body and its attributes. In cultural, gender and gender studies are seen as social constructs that are intrinsically implicated in representational issues. Gender and gender are more a cultural problem than natural (natural). Gender is the name for a social role built on the sex, this is different from sex that refers to the biological category. Gender identity is concerned 
with the differentiation of women ( feminist) and male (masculine) roles in cultural and social outlook. Feminism addresses the languages that play a role in shaping identity and constructing subjectivity. In particular, the language becomes a tool against the patriarchal culture and imperialist powers. The feminists are trying to dig and utilize the " sense of disarticulation " of the language of the legacy and restore the authenticity of the language based on the language of pre-colonial. The text of feminist theory is closely related to the theory of identity in the dominant discourse. This theory offers various strategies of resistance to control that determine the meaning of women's identity.

Hall (1990) considers identity as the name for a collection of one's true self and imagined identity formed by history, ancestors and a set of similar symbolic sources. For example, British identity is expressed through Union Jack (Barker.2005: 231), Appalachia by residence (Utz, 2001). Based on the development of ideas about the cultural identity that deliberately, formed and built the King (1982), Vickers (1989) and Wood (1998), but among the intellectuals mutually disagree on how far the construction of cultural identity associated with certain processes and different historical experiences.

In the definition of Self, the Other is at least implicitly identified, as it defines another implicit characteristic of Self. Ricoeur notes that " the Other " is not only co-balanced of The Same but is also owned by the constitution depth of meaning itself (The intimate constitute of its sense) "(1992: 329), and focus on the way in which the Other members of the the Self (strongly reminiscent of a symbolic interactive point of view) through identification of "in" or " with " others (1992: 121). As the name might put the self, they may put the other in a wider or narrower share of ownership. This ownership is not directly expressed through relationships, a community defined through interaction. In places where interactional identification occurs, physical and behavioral attributes may be compatible with definitional primacy in characterizing who they are. Here name identity of the other in relation to the key characteristics: the key unlocks the core of living things, sums up everything that is important to know, the knowledge is clearly related to the power.

The explanation of the question of the meaning of identity in the mind of personal identity, a person begins to start with the formulation of how one defines who he is, defines himself or understands himself. Again, however, it is really that many differences between him male with her female. Which is exactly related to personal identity? And self-understanding is broader and more real to be true. Some objects may be rationally included in the self-understanding will not be said as identity objects. This is as to why Brubaker and Cooper (1999) suggest that selfunderstanding is more precise than the identity associated with it.

\section{CONCLUSION}

Construction of society on multiculturalism shows that society, in the southern slope of Kelud Mountain until those who live in mountains, shows high solidarity and harmony than those who live in lands. In fact, the tentative conclusion said that more they live to the mountains, the more solid and harmonious life they have, while the more they live to the lands, the less solid and indicated less harmony of life as the effect of more individuality life.

Events that can increase solidity and solidarity are their activities, for example, that ritual of sanitizing village, some activities to celebrate the Independence Day, holidays of religions, Ied Mubarak, Christmas, Galungan and Kuningan and others. Solidarity and solidity need to be developed continuously, with an expectation that it can increase not only a plural reality but also multiculturalism culture. There is an interesting phenomenon that they also appreciate and respect what is known as the true brotherhood between society member that relatively different from religion, race or even culture.

A place where art and culture can grow and develop well also indicate that society that lived there can have high tolerance on plurality or multiculturalism. It means that ancient arts are needed to be managed and maybe it is needed to be developed. The important suggestion is the 
political spark and or political interest ought to be minimized. From the premises, it is time to avoid the use of ethnic, religion, race and parties issues for the sake of fighting over the political area and or political power.

Properly, elites in local platform always try to develop multicultural life. It is not only developed the plural reality but also multicultural reality should be developed. It is needed to give facilities to resurrect art culture that nowadays has been dying, apparent death or has no supporters. Jaranan, Reog, Human Puppet (Wayang Orang), puppet (Wayang Kulit) are necessary needs to be developed. In short, the government should be careful and facilitates it, in order to make it eternal and develop it as regional art.

\section{REFERENCE}

Castells, Manuel. 2004. The Rise of the Network Society,Volume I. Second edition (Malden USA: Blackwell Publishing, 2004). 21. Manuel Castells. The Rise of the Network Society,Volume I. Second edition (Malden USA: Blackwell Publishing). 21.

Daeng, Hans J. 2000. Manusia, Kebudayaan dan Lingkungan. Tinjauan antropologis. (Yogyakarta: Pustaka Pelajar)

Daniel Sparringa. 2005. "Multikulturalisme sebagai Respon Alternatif terhadap Politik Identitas dan Resolosi Konflik yang bersifat Transformatif: sebuah Perspektif Sosiologi Politik. Makalah disajikan dalam Kursus dan Pelatihan HAM di UGM Jogyakarta (28 Nopember-2 Desember)

Dreher, Jochen. 2015. "The Construction of Power: Reflections Beeyond Berger/Luckmann and Boudieu" Dalam Journal Cultural Sociology.I-16. Cus.sagepub.com

Dreher, Jochen. 2015. "The Construction of Power: Reflections Beyond Berger/Luckmann and Boudieu" Dalam Journal Cultural Sociology. I-16. Cus.sagepub.com

Fearon, James D. 1999. "What is identity (as we now) use the word)? hal. 20

Franks, Bradley. 2014. " Social Construction, Evolutions and Cultural Universals" Dalam Cultural and Psychology. Vol 20 (3) 416-439. Cap.sagepub.com

Franks, Bradley. 2014. " Social Construction, Evolutions and Cultural Universals" Dalam Cultural and Psychology. Vol 20 (3) 416-439. Cap.sagepub.com

Friedman, Asia M. 2015. "Perceptual Construction: Rereading the Social Construction of Reality Through the Sociology of Senses” Dalam Cutural Spciology. I-16 cus.sagepub.com

Friedman, Asia M. 2015. "Perceptual Construction:Rereading the Social Construction of Reality Through the Sociology of Senses" Dalam Cutural Spciology. I-16 cus.sagepub.com

George A. Akerlof and Rachel E. Kranton. "Economic and identity" Dalam The Quarterly Journal of Economics Vol. CXV Issue 3 (August 2000) 715-749 Maunati, Yekti. Identitas Dayak. (Yogyakarta: Lkis, 2004) H. 23- 47.

Gozdecka, Dorota A dkk. 2014. "From Multiculturalism to Post-multiculturalism: Trends and paradoxes" Dalam Journal of Sociology. 2014.Vol.50(1) 51-64. Jos.sagepub.com

Gozdecka, Dorota A dkk. 2014. "From Multiculturalism to Post-multiculturalism: Trends and paradoxes" Dalam Journal of Sociology. 2014.Vol.50(1) 51-64. Jos.sagepub.com

Pakulski, Jan. 2014. "Confusions about Multiculturalism” Dalam Journal of Sociology. 2014. Vol. 50 (1) 23 - 36. Jos.sagepub.com

Pakulski, Jan. 2014. "Confusions about Multiculturalism” DalamJournal of Sociology. 2014. Vol. 50 (1) 23 - 36. Jos.sagepub.com

Paul van der Grijp. Identity and Development. Tongan Culture, Agriculture, and the pereniality of the gift. Leiden: KITLV Press. 2004

Scuzzarello, Sarah. 2015. "Caring Multiculturalism: Power and Transformation in diverse societies" Dalam Journal Feminis Theory. 2015. Vol. 16 (1) 67-86.fty.sagepub.com 
Scuzzarello, Sarah. 2015. "Caring Multiculturalism:Power and Transformation in diverse societies" Dalam Journal Feminis Theory. 2015. Vol. 16 (1) 67-86.fty.sagepub.com

Sukamto. 2013. Sengketa Perbatasan Kabupaten Blitar dan Kediri. Malang: LP2 Univerrsitas Negeri Malang

Sukamto. 2014. Identifikasi Potensi Multikulturalisme di Garum kabupaten Blitar. LP2 Universitas Negeri Malang

Sukamto.2010. “ Politik Identitas (Suatu Kajian Awal dalam Kerangka dan Ineraksi Lokalitas dan Globalisasi”) Dalam Sejarah dan Budaya. Jurnal Sejarah, Budaya dan Pengajarannya. Tahun Ketiga Nomer 1, Juni 2010. 9-23

Sukamto.2010. "Tindakan Kolektif dan Identitas (Studi Fenomenologis Korban Lumpur Lapindo di Porong Sidoarjo" Dalam Sejarah dan Budaya. Jurnal Sejarah, Budaya dan Pengajarannya. Tahun Ketiga Nomer 1, Juni 2010.81-100

Sukamto.2013. "Fenomena Korban Lumpur Lapindo, tindakan Kolektif, produksi Identitas dan Fenomenologi” Dalam Sejarah dan Budaya. Jurnal Sejarah, Budaya dan Pengajarannya. Tahun Ketujuh Nomer 1, Juni 2013.76-95.

Sukamto.2013. Sengketa Perbatasan Kabupaten Blitar dan Kediri.Malang: LP2 Universitas Negeri Malang

Sukamto.2014. Identifikasi Potensi Multikulturalisme di Garum kabupaten Blitar. LP2 Universitas Negeri Malang

Sukamto.2015. Konstruksi Masyarakat desa Ngaringan atas Multikulturalisme di Kecamatan gandusari kabupaten Blitar. LP2 Univesitas Negeri Malang

Sukamto.2015. Konstruksi Masyarakat desa Ngaringan atas Multikulturalisme di Kecamatan gandusari kabupaten Blitar. LP2 Univesitas Negeri Malang

Sukamto.I Nyoman Ruja dan Agus Purnomo. 2016. Masyarakat Lereng Selatan Gunung Kelud

Sukamto.I Nyoman Ruja dan Agus Purnomo. 2016. Masyarakat Lereng Selatan Gunung Kelud (Studi Konstruksi Sosial Multikultural di Kabupaten Blitar.

Sukamto.I Nyoman Ruja.2016. "Social construction on Cultural Multiculturalism” Dalam The 4th International Conference. Language, Society, and Culture in Asian Contexs. (LSCAC 2016) May 24-25, 2016 an Hotel atria Malang.

Winter, Elke. 2015. "Rethinking Multiculturalism After is "Retreat": Lessons From Canada" Dalam American Behaiorl Scienctist. 2015. Vol.59(6) 637-657. Abs.sagepub.com

Winter, Elke. 2015. "Rethinking Multiculturalism After is "Retreat": Lessons From Canada" Dalam American Behavioral Scienctist. 2015. Vol.59(6) 637-657. Abs.sagepub.com

Zerubavel. Eviatar. 2015. "The five Pillars of Essentialism Reification and the Social construction of an Objective Realitiy" Dalam Journal Cultural Sociology I-8. cus.

Zerubavel.Eviatar. 2015. "The five Pillars of Essentialism Reification and the Social construction of an Objective Realitiy” Dalam Journal Cultural Sociology I-8.cus. 